\title{
Distribution of Uranium and Thorium in Soil and Woody Plants of Eastern Siberia (Irkutsk Region)
}

\author{
Sergey G. Shvetsov and Viktor I. Voronin* \\ Siberian Institute of Plant Physiology \\ and Biochemistry of $S B$ RAS \\ 132 Lermontov Str., Irkutsk, 664033, Russia
}

Received 28.01.2016, received in revised form 28.03.2016, accepted 23.05.2016, published online 04.11.2017

Uranium and thorium contents in soils and plants of pine forests on the south of Eastern Siberia were investigated. This region is a major wood supplier, therefore the survey of radioactive elements concentration in wood is a subject of practical interest. Concentrations of uranium and thorium were determined in soil samples, in trees (aboveground parts and roots of Pinus sylvestris, Larix sibirica, and Betula pendula), and in ground cover plants. Samples analysis included ashing, dissolution in nitric acid, extraction of radionuclides by tributylphosphate, ion-exchange separation, and measurement of radioactivity with liquid scintillation counter 1219 RackBeta-Spectral. The major characteristic of all studied ecosystems was that the highest thorium and uranium concentrations in the ash of various parts of the forest forming species (pine and larch) were measured in roots; the lowest concentrations were in needles. Radionuclides concentrations in the ash from the trees growing on the soddy-podzol soils were noticeably higher than that from the trees growing on the soddy-forest soils. The average uranium content ranged from 1.44 to $2.72 \mathrm{mg} \mathrm{kg}^{-1}$ in the soils of the studied region and from 0.049 to $0.169 \mathrm{mg} \mathrm{kg}^{-1}$ in the wood ash. The average thorium content reached $4.18-8.23 \mathrm{mg} \mathrm{kg}^{-1}$ in the soils and $0.146-0.767 \mathrm{mg} \mathrm{kg}^{-1}$ in the plants ash. The average contents of uranium and thorium in the ash of the ground cover plants were from 0.046 to $0.387 \mathrm{mg} \mathrm{kg}^{-1}$ and from 0.205 to $0.515 \mathrm{mg} \mathrm{kg}^{-1}$, respectively.

Keywords: Pine forests, Eastern Siberia, uranium, thorium, distribution in soil and wood.

Citation: Shvetsov S.G., Voronin V.I. Distribution of uranium and thorium in soil and woody plants of Eastern Siberia (Irkutsk Region). J. Sib. Fed. Univ. Biol., 2019, 12(1), 86-100. DOI: 10.17516/1997-1389-0035.

(C) Siberian Federal University. All rights reserved

* Corresponding author E-mail address: bioin@sifibr.irk.ru 


\section{Распределение урана и тория в почве \\ и растениях Восточной Сибири \\ (Иркутская область)}

С.Г. Швецов, В.И. Воронин

Сибирский институт физиологии и биохимии растений СО РАН

Россия, 664033, Иркутск, ул. Лермонтова, 132

Было исследовано содержание урана и тория в почвах и растениях сосновых лесов на юге Восточной Сибири. Этот регион является крупным поставщиком древесины, поэтому информация о содержании в ней радионуклидов представляет также и практический интерес. Кончентрачия урана и тория определялась в пробах почвы, древесных растениях (надземные части и корни Pinus sylvestris, Larix sibirica, Betula pendula), а также в покровных растениях (кустарнички, травянистые растения и мхи). Для анализа образцов использовалась модифииированная методика, включавшая озоление, растворение в азотной кислоте, экстракцию радионуклидов трибутилфосфатом, ионообменное разделение и измерение радиоактивности сцинтилляционным жидкостным счетчиком 1219 RackBeta-Spectral. Характерным для всех изученных экосистем было то, что самые высокие концентрации тория и урана у древесных растений были обнаружены в корнях, а самая низкая концентрация этих элементов отмечена для хвои (листьев). Содержание радионуклидов в золе деревьев, растущих на дерново-подзолистых почвах, была заметно выше, чем у растущих на дерново-лесных почвах. Среднее содержание урана в почвах находилось в переделах 1,44-2,72 мг/кг, а в золе стволов деревьев - 0,049-0,169 мг/кг. Среднее содержание тория в почвах достигало 4,18-8,23 мг/кг, в золе стволов деревьев - 0,146-0,767 мг/кг. В золе покровных растений содержание урана находилось в пределах от 0,046 до 0,387 мг/кг; тория - от 0,205 до 0,515 мг/кг.

Ключевые слова: сосновые леса, Восточная Сибирь, уран, торий, распределение в почве и растениях.

\section{Введение}

Рациональное природопользование связано с решением разнообразных вопросов, в том числе и вопросов радиационной безопасности. В нормальных условиях (отсутствие последствий радиационных аварий или испытаний ядерного оружия) основным источником радиации в биосфере являются литосферные долгоживущие радионуклиды, например уран $\left({ }^{238} \mathrm{U},{ }^{235} \mathrm{U}\right)$ и торий $\left({ }^{232} \mathrm{Th}\right)$. Вовлечение этих элементов в биологический круговорот происходит на уровне экосистемы: сначала они попадают в почву и растения, затем по трофическим путям и/или в результате переноса распространяются в биосфере. Степень влияния урана и тория на экосистему определяется их содержанием в живых организмах и в среде обитания.

Лесные ландшафты, преобладающие на большей части территории России (в том 
числе и на территории Иркутской области), активно используются как источники древесины и рекреационные объекты. Поэтому определение содержания урана и тория в различных компонентах лесных экосистем имеет большое экологическое значение. Результаты количественных определений урана и тория в почве и растениях различных экосистем, в том числе и лесных, приводились в ряде работ (Гродзинский, 1965; Титаева, Таскаев, 1984; Тяжелые естественные радионуклиды..., 1990; Титаева, 2000). Опубликованы данные по распределению урана и тория в окружающей среде Прибайкалья (Grebenshchikova et al., 2009; Grebenshchikova et al., 2010). Кроме региональных количественных различий приведенные данные позволяют сделать общий вывод: уровни урана и тория в растениях определяются содержанием этих элементов в почве и почвообразующей породе. Несмотря на значительный прогресс в области радиационной экологии, остаются недостаточно изученными как общие закономерности аккумуляции и распределения урана и тория в лесных экосистемах, так и их региональные особенности.

Цель настоящей работы - определить содержание урана и тория в почвах и растениях, изучить закономерности аккумуляции этих элементов в зависимости от почвеннорастительных характеристик некоторых лесных экосистем Юго-Западного Прибайкалья. Задачи исследования: определить видовой состав и оценить биомассу компонентов фитоценозов; определить основные морфологические, физические и химические характеристики почв; измерить валовое содержание урана и тория в почвенных горизонтах и почвообразующей породе; определить содержание урана и тория в древесных и покровных растениях; оценить общий ха- рактер и особенности распределения урана и тория в изучаемых экосистемах.

\section{Материалы и методы}

Район исследований располагается в нижнем течении р. Иркут, на расстоянии 50-60 км юго-западнее г. Иркутска на территории, прилегающей к предгорьям Восточного Саяна. Склоны возвышенностей (со средней крутизной $8^{\circ}-10^{\circ}$ ) и водоразделы занимают свыше 80 \% территории. Климат района резко континентальный с большими колебаниями годовых положительных и отрицательных температур, небольшим количеством осадков с неравномерным их сезонным распределением. Почвообразующими породами являются среднесуглинистые и тяжелосуглинистые четвертичные отложения, образованные из пород кембрийского и юрского возраста, на которых формируются преимущественно дерновые лесные, дерново-карбонатные и дерново-подзолистые почвы (Атлас..., 1962; Почвы..., 1979). Территория района занята светлохвойными лесами и связанными с ними лугово-кустарниковыми и болотными ассоциациями (Леса и лесное хозяйство..., 1997).

Для настоящего исследования были выбраны два участка, расположенные друг от друга на расстоянии 20 км. Каждый участок располагался на привершинной части увалов, покрывая водораздел и противоположные склоны. На 1-м участке преобладали разнотравно-брусничные сосновые (Pinus sylvestris L.) леса на дерновых лесных почвах. На 2-м участке располагались разнотравные сосновые леса с примесью лиственницы (Larix sibirica Ledeb.) и березы (Betula pendula Roth) на дерново-подзолистых почвах. На южном склоне, водоразделе и северном склоне каждого участка было заложено по пробной пло- 
щади $\left(500 \mathrm{~m}^{2}\right)$. Расстояние между площадями $350-500$ м.

По стандартным методикам (Manual..., 1994; Добровольский, 2001; Усольцев, 2002) определяли лесотаксационные и почвенные характеристики: состав древостоя, массу стволов, листьев, и корней деревьев; состав, общую массу надземных частей и корней травяно-кустарничково-мохового покрова, строение почвенного профиля, содержание гумуса, гранулометрический состав, $\mathrm{pH}_{\text {сол }}$, емкость катионного обмена. Почвенные анализы проводились в 4-кратной повторности. Свойства почв в таблице представлены в виде средних значений. Относительный доверительный интервал составлял 7,5 \% при 95,5\%-ном уровне вероятности.

Образцы древесины для определения содержания урана и тория брали от 3-6 деревьев каждого вида возрастом 50-70 лет и высотой от 8 до 12 м из стволов на высоте 1,0-1,5 м и прикомлевых (1,0-1,5 м от ствола) скелетных корней. Листья и хвою набирали из срезанных с высоты 4-6 м ветвей тех же деревьев. Для анализов использовали объединенные образцы.

Материал для образцов кустарничковотравяно-мохового покрова собирали с не-

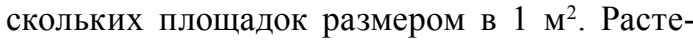
ния выкапывали вместе с корневой системой, отмывали от почвы и распределяли по трем группам (кустарнички, мхи и разнотравье), разделяли на надземную и корневую части. Для анализов использовали объединенные образцы.

Содержание урана и тория в почвенных и растительных образцах определяли по модифицированной методике (Методические рекомендации ..., 1980). Все анализы проводили в 4-кратной повторности. Растительные образцы высушивали и затем озоляли в муфельной печи. Золу растворяли в азотной кислоте, полученный раствор экстрагировали трибутилфосфатом, экстракт разделяли с помощью ионообменной смолы, затем определяли радиоактивность полученных фракций. Почвенные образцы высушивали, озоляли в муфельной печи, к золе добавляли фтористый аммоний для удаления силикатных примесей. Полученный материал растворяли в азотной кислоте, раствор экстрагировали трибутилфосфатом, экстракт разделяли с помощью ионообменной смолы, после чего в полученных фракциях определяли радиоактивность.

Измерение радиоактивности полученных образцов проводили на жидкостном сцинтилляционном радиометре LKB Wallak 1219 RackBeta-Spectral. С помощью стандартных препаратов урана и тория прибор настраивали на регистрацию характеристического излучения этих радионуклидов при фоне прибора 6 импульс/мин и относительной точности отдельного измерения $\pm 10 \%$ (Швецов и др., 2006). Определение массы урана и тория в опытных образцах проводили путем сравнения со стандартными образцами этих радионуклидов. В таблицах представлены средние значения полученных данных, относительный доверительный интервал находился в пределах 17-20 \% при 95\%-ном уровне вероятности.

\section{Результаты и обсуждение}

Исследуемые фитоценозы были представлены сосновыми лесами с примесью лиственницы и березы с развитым кустарничковотравянистым покровом (табл. 1). Почвы района исследования дерновые лесные и дерновоподзолистые; по новой классификации (Шишов и др., 2004) им соответствуют буроземы в отделе структурно-метаморфических почв и дерново-подзолистые в отделе текстурнодифференцированных почв. 
Таблица 1. Основные характеристики исследуемых экосистем и сухая масса растений (т/га)

Table 1. The main characteristics of ecosystems and dry weight of plants (t/ha)

\begin{tabular}{|c|c|c|c|c|c|}
\hline \multirow{2}{*}{$\begin{array}{c}\text { № пробной площади, тип леса, } \\
\text { состав древостоя, количество стволов/га, } \\
\text { элемент рельефа, почва }\end{array}$} & \multicolumn{3}{|c|}{ Деревья } & \multicolumn{2}{|c|}{ Покровные растения } \\
\hline & $\begin{array}{l}\text { Стволы } \\
\text { и ветви }\end{array}$ & $\begin{array}{c}\text { Хвоя } \\
\text { (листья) }\end{array}$ & Корни & $\begin{array}{c}\text { Надземные } \\
\text { органы }\end{array}$ & Корни \\
\hline $\begin{array}{l}\text { 1, бруснично-зеленомошный, 7С2Л1Б+К, 550, } \\
\text { северо-восточный склон } 10^{\circ} \text {, дерновая лесная }\end{array}$ & 74,9 & 2,7 & 25,8 & 1,41 & 0,93 \\
\hline $\begin{array}{l}\text { 2, бруснично-разнотравный, 7С2Л1Б, 650, } \\
\text { водораздел, дерновая лесная }\end{array}$ & 79,5 & 3,2 & 26,2 & 1,35 & 0,97 \\
\hline $\begin{array}{l}\text { 3, бруснично-разнотравный, 8С2Л+Б, 520, } \\
\text { юго-западный склон } 15^{\circ} \text {, дерновая лесная }\end{array}$ & 71,6 & 2,8 & 27,1 & 1,42 & 1,28 \\
\hline $\begin{array}{l}\text { 4, бруснично-разнотравный, 8С2Л+Б, 670, } \\
\text { северный склон } 8^{\circ} \text {, дерново-подзолистая }\end{array}$ & 64,2 & 2,9 & 23,5 & 1,33 & 1,24 \\
\hline $\begin{array}{l}\text { 5, бруснично-разнотравный, 9С1Л+Б, 720, } \\
\text { водораздел, дерново-подзолистая }\end{array}$ & 70,7 & 2,9 & 23,7 & 1,24 & 0,98 \\
\hline $\begin{array}{l}\text { 6, разнотравный, 8С1Л1Б, 620, южный склон } \\
10^{\circ} \text {, дерново-подзолистая }\end{array}$ & 72,9 & 3,3 & 26,3 & 1,27 & 1,02 \\
\hline
\end{tabular}

Свойства почв. Основные почвенные характеристики показаны в табл. 2. Анализируемые почвы имели некоторые различия между собой, обусловленные свойствами почвообразующих пород. Почва первого фитоценоза сформировалась на делювии продуктов выветривания юрских песчаников и отличалась практически равномерным распределением по профилю илистых фракций с небольшим относительным максимумом в иллювиальном горизонте. Гумусовый профиль ясно выделялся не только морфологически, но и аналитически по абсолютному содержанию гумуса и повышенным значениям емкости катионного обмена. Почва второго фитоценоза, расположенная на водоразделе в элювиальном ландшафте, отличалась от предыдущей наличием карбонатов в почвообразующей породе, что хорошо видно по значениям рН горизонта $\mathrm{C}$.

Дерновая почва третьего фитоценоза занимала юго-западный склон крутизной $15^{\circ}$, что отражается в сравнении с предыдущими почвами в относительно низком содержании гумуса. Если почвы трех первых фитоценозов относятся к типу почв «дерновые лесные», то последующие фитоценозы сформировались на дерново-подзолистых почвах, отличающихся от дерновых лесных дифференцированным профилем. В дерново-подзолистых почвах, на которых сформировались четвертый, пятый и шестой фитоценозы, заметно выделялся переходный эллювиально-иллювиальный горизонт А2В и иллювиальные горизонты, расположенные ниже по профилю. Горизонты А2В содержали меньшее количество илистых фракций, менее насыщены основаниями, и по этой причине их актуальная реакция имела меньшие значения. Следует заметить, что район исследования отличается пестротой коренных пород, представленных отложениями кембрия и юры. По водоразделам юрские песчаники покрывают отложения красных алевролитов верхнего кембрия. В тех местоположениях, где образования юры разрушены, нижние горизонты почвообразующих пород могут содержать карбонаты кембрийских алевролитов. Повышенное содержание гумуса объясняется выровненностью рельефа водораздельной поверхности, не способству- 
Таблица 2. Некоторые свойства почв исследуемых экосистем

Table 2. Some properties of soils of the studied ecosystems

\begin{tabular}{|c|c|c|c|c|c|}
\hline $\begin{array}{c}\text { № разреза, } \\
\text { горизонт }\end{array}$ & Глубина, см & $\mathrm{pH}$ & Гумус, \% & $\begin{array}{c}\text { Емкость катионного } \\
\text { обмена, мг-экв/100 г почвы }\end{array}$ & $\begin{array}{c}\text { Содержание фракции } \\
<0,001 \text { мм, \% } \\
\end{array}$ \\
\hline $1, \mathrm{~A} 0$ & $0-4$ & 5,9 & н.о. & H.O. & H.o. \\
\hline $1, \mathrm{~A} 1$ & $4-11$ & 6,1 & 3,72 & 38 & 17 \\
\hline $1, \mathrm{~A} 1$ & $11-19$ & 6,0 & 3,72 & 39 & 19 \\
\hline $1, \mathrm{~B}$ & $19-43$ & 6,3 & 0,62 & 26 & 23 \\
\hline $1, \mathrm{BC}$ & $43-63$ & 6,1 & 0,20 & 21 & 17 \\
\hline $1, \mathrm{C}$ & $63-105$ & 6,2 & 0,10 & 18 & 15 \\
\hline $2, \mathrm{~A} 0$ & $0-3$ & H.o. & н.о. & H.O. & H.O. \\
\hline $2, \mathrm{~A} 1$ & $3-10$ & 6,2 & 4,41 & 33 & 14 \\
\hline $2, \mathrm{~A} 1$ & $10-21$ & 6,1 & 4,22 & 34 & 14 \\
\hline $2, \mathrm{~B}$ & $21-54$ & 6,4 & 0,47 & 21 & 17 \\
\hline $2, \mathrm{BC}$ & $54-77$ & 6,9 & 0,19 & 17 & 12 \\
\hline $2, \mathrm{C}$ & $77-133$ & 7,8 & 0,09 & 14 & 9 \\
\hline $3, \mathrm{~A} 0$ & $0-2$ & H.o. & н.о. & H.о. & H.о. \\
\hline $3, \mathrm{~A} 1$ & $2-7$ & 6,2 & 2,62 & 31 & 19 \\
\hline $3, \mathrm{~A} 1$ & $7-11$ & 6,1 & 2,51 & 33 & 19 \\
\hline $3, \mathrm{~B}$ & $11-34$ & 6,8 & 0,11 & 17 & 22 \\
\hline $3, \mathrm{BC}$ & $34-72$ & 7,2 & 0,06 & 14 & 14 \\
\hline $3, \mathrm{C}$ & $72-95$ & 6,8 & 0,11 & 17 & 22 \\
\hline $4, \mathrm{~A} 0$ & $0-2$ & H.o. & H.о. & H.O. & H.O. \\
\hline 4, A1 & $2-7$ & 6,1 & 5,13 & 39 & 15 \\
\hline 4, A1 & $7-11$ & 6,0 & 4,93 & 38 & 16 \\
\hline $4, \mathrm{~A} 2 \mathrm{~B}$ & $11-21$ & 5,7 & 3,08 & 12 & 14 \\
\hline 4, B & $21-42$ & 5,9 & 1,03 & 24 & 19 \\
\hline $4, \mathrm{BC}$ & $42-76$ & 6,0 & 0,51 & 22 & 18 \\
\hline $4, \mathrm{C}$ & $76-110$ & 6,2 & 0,41 & 15 & 15 \\
\hline $5, \mathrm{~A} 0$ & $0-2$ & H.о. & H.о. & H.о. & H.O. \\
\hline $5, \mathrm{~A} 1$ & $2-5$ & 5,8 & 4,68 & 38 & 15 \\
\hline 5, A1 & $5-8$ & 5,7 & 4,49 & 37 & 16 \\
\hline $5, \mathrm{~A} 2 \mathrm{~B}$ & $8-22$ & 5,5 & 2,81 & 12 & 14 \\
\hline 5, B & $22-50$ & 5,9 & 0,94 & 24 & 20 \\
\hline $5, \mathrm{BC}$ & $50-96$ & 6,0 & 0,47 & 22 & 20 \\
\hline $5, \mathrm{C}$ & $96-146$ & 6,2 & 0,37 & 15 & 16 \\
\hline $6, \mathrm{~A} 0$ & $0-2$ & H.o. & H.O. & H.O. & H.O. \\
\hline $6, \mathrm{~A} 1$ & $2-7$ & 5,7 & 4,65 & 38 & 19 \\
\hline $6, \mathrm{~A} 1$ & $7-12$ & 5,6 & 4,57 & 37 & 21 \\
\hline $6, \mathrm{~A} 2 \mathrm{~B}$ & $12-22$ & 5,4 & 2,45 & 12 & 17 \\
\hline $6, \mathrm{~B}$ & $22-53$ & 5,6 & 0,82 & 23 & 21 \\
\hline $6, \mathrm{BC}$ & $53-101$ & 5,6 & 0,41 & 22 & 20 \\
\hline $6, \mathrm{C}$ & $101-144$ & 5,8 & 0,33 & 15 & 16 \\
\hline
\end{tabular}

Примечание: н.о. - не определяли.

ющей сносу гумусированного материала вниз по склону.

Содержание радионуклидов в почвах. Распределение валового содержания урана и тория в исследуемых почвах было неравномерным, хотя характер распределения в дерново-подзолистой и дерновой лесной почвах был, в основном, сходным (табл. 3). Концентрация этих элементов была максимальной в аккумулятивных горизонтах, с глубиной постепенно снижаясь до величин, свойственных почвообразующей породе. Средневзвешенное 
Таблица 3. Содержание урана и тория в почвах исследуемых экосистем (мг/кг)

Table 3. The contents of uranium and thorium in soils of the studied ecosystems $(\mathrm{mg} / \mathrm{kg})$

\begin{tabular}{|c|c|c|c|c|c|c|c|c|}
\hline \multirow{2}{*}{ № разреза } & \multirow{2}{*}{ Элемент } & \multicolumn{7}{|c|}{ Почвенные горизонты } \\
\cline { 3 - 9 } & & $\mathrm{A}_{0}$ & $\mathrm{~A}_{1}$ & $\mathrm{~A}_{2} \mathrm{~B}$ & $\mathrm{~B}$ & $\mathrm{BC}$ & \multicolumn{2}{c|}{$\begin{array}{c}\text { Среднее } \\
\left(\mathrm{A}_{1} \text {-ВС) }\right.\end{array}$} \\
\hline \multirow{2}{*}{1} & $\mathrm{U}$ & 0,32 & 2,40 & - & 2,37 & 1,98 & 1,57 & 2,23 \\
& $\mathrm{Th}$ & 0,93 & 8,26 & - & 5,26 & 6,58 & 4,14 & 6,41 \\
\hline \multirow{2}{*}{2} & $\mathrm{U}$ & 0,33 & 3,34 & - & 3,06 & 2,17 & 0,95 & 2,72 \\
& $\mathrm{Th}$ & 0,77 & 5,80 & - & 5,27 & 4,98 & 2,31 & 5,26 \\
\hline \multirow{2}{*}{3} & $\mathrm{U}$ & 0,28 & 1,81 & - & 1,58 & 1,17 & 1,11 & 1,44 \\
& $\mathrm{Th}$ & 0,62 & 5,78 & - & 4,63 & 3,64 & 2,65 & 4,18 \\
\hline \multirow{2}{*}{4} & $\mathrm{U}$ & 0,21 & 3,24 & 1,86 & 1,92 & 1,29 & 1,39 & 1,68 \\
& $\mathrm{Th}$ & 1,67 & 14,92 & 7,55 & 7,38 & 4,79 & 5,49 & 6,87 \\
\hline \multirow{2}{*}{5} & $\mathrm{U}$ & 0,77 & 1,91 & 2,05 & 2,22 & 1,84 & 1,93 & 2,02 \\
& $\mathrm{Th}$ & 2,88 & 11,81 & 8,42 & 8,76 & 7,39 & 7,61 & 8,23 \\
\hline \multirow{2}{*}{6} & $\mathrm{U}$ & 0,77 & 2,87 & 2,55 & 2,53 & 1,68 & 2,14 & 2,12 \\
& $\mathrm{Th}$ & 2,49 & 10,72 & 10,20 & 9,73 & 5,92 & 8,17 & 7,98 \\
\hline
\end{tabular}

Таблица 4. Содержание золы в различных частях растений исследуемых экосистем (над чертой - \%, под чертой - кг/га)

Table 4. Ash content in different parts of plants in the studied ecosystems (above the slash $-\%$, below the slash $\mathrm{kg} / \mathrm{ha})$

\begin{tabular}{|c|c|c|c|c|c|}
\hline \multirow{2}{*}{ № ПП } & \multicolumn{3}{|c|}{ Деревья } & \multicolumn{2}{c|}{ Покровные растения } \\
\cline { 2 - 6 } & Стволы & Хвоя (листья) & Корни & $\begin{array}{c}\text { Надземные } \\
\text { органы }\end{array}$ & Корни \\
\hline 1 & $0,67 / 500$ & $3,52 / 95$ & $2,22 / 570$ & $5,27 / 74$ & $6,92 / 64$ \\
\hline 2 & $0,69 / 548$ & $3,23 / 87$ & $2,41 / 631$ & $5,56 / 78$ & $6,03 / 58$ \\
\hline 3 & $0,72 / 515$ & $3,45 / 96$ & $2,15 / 582$ & $5,75 / 81$ & $6,34 / 81$ \\
\hline 4 & $0,60 / 385$ & $2,96 / 85$ & $2,85 / 670$ & $4,38 / 58$ & $5,28 / 67$ \\
\hline 5 & $0,64 / 452$ & $3,04 / 88$ & $2,78 / 540$ & $4,98 / 62$ & $5,74 / 56$ \\
\hline 6 & $0,63 / 459$ & $3,12 / 103$ & $2,93 / 771$ & $5,10 / 64$ & $6,17 / 63$ \\
\hline Среднее & $0,66 / 477$ & $3,22 / 92$ & $2,56 / 627$ & $5,17 / 70$ & $6,10 / 65$ \\
\hline
\end{tabular}

содержание урана в корнеобитаемом слое (горизонты А1-ВС) дерновой лесной почвы изменялось от 1,44 до 2,72 мг/кг, тория - от 4,18 до 6,41 мг/кг. Те же показатели для почв дерново-подзолистого ряда составляли 1,682,12 и 6,87-8,23 мг/кг соответственно.

Зольность растений. В табл. 4 представлены данные по общей зольности древесной и покровной растительности исследуемых фитоценозов. Самое низкое содержание золы у лась. деревьев было в стволах - от 0,60 до 0,72 \%, а самое высокое наблюдалось в хвое (листьях) от 2,96 до 3,52 \%. Несколько ниже была зольность корней - от 2,15 до 2,93 \%. Зольность покровных растений была значительно выше зольности деревьев. Этот показатель в корнях достигал 6,92 \%, а в надземной массе - 5,75 \%. Зависимость зольности растений и их частей от типа фитоценоза отчетливо не проявля- 
Таблица 5. Содержание урана и тория в древесных растениях исследуемых экосистем (мг/кг золы)

Table 5. The contents of uranium and thorium in woody plants of the studied ecosystems ( $\mathrm{mg} / \mathrm{kg}$ ash)

\begin{tabular}{|c|l|c|c|c|c|c|c|}
\hline \multirow{2}{*}{ № ПП } & \multirow{2}{*}{ Растение } & \multicolumn{2}{|c|}{ Корни } & \multicolumn{2}{c|}{ Ствол } & \multicolumn{2}{c|}{ Хвоя (листья) } \\
\cline { 3 - 8 } & & $\mathrm{U}$ & $\mathrm{Th}$ & $\mathrm{U}$ & $\mathrm{Th}$ & $\mathrm{U}$ & $\mathrm{T}$ \\
\hline \multirow{2}{*}{1} & Сосна & 0,074 & 0,212 & 0,060 & 0,177 & 0,060 & 0,152 \\
& Лиственница & 0,071 & 0,210 & 0,054 & 0,174 & 0,052 & 0,139 \\
& Береза & 0,085 & 0,191 & 0,049 & 0,158 & 0,045 & 0,113 \\
\hline \multirow{2}{*}{2} & Сосна & 0,124 & 0,287 & 0,120 & 0,246 & 0,061 & 0,135 \\
& Лиственница & 0,119 & 0,272 & 0,112 & 0,231 & 0,049 & 0,110 \\
& Береза & 0,143 & 0,259 & 0,139 & 0,206 & 0,049 & 0,098 \\
\multirow{3}{*}{3} & Сосна & 0,071 & 0,196 & 0,071 & 0,173 & 0,055 & 0,151 \\
& Лиственница & 0,064 & 0,186 & 0,062 & 0,163 & 0,044 & 0,124 \\
& Береза & 0,079 & 0,177 & 0,069 & 0,146 & 0,045 & 0,106 \\
\hline \multirow{2}{*}{4} & Сосна & 0,149 & 0,602 & 0,138 & 0,570 & 0,118 & 0,488 \\
& Лиственница & 0,136 & 0,560 & 0,125 & 0,526 & 0,092 & 0,368 \\
& Береза & 0,154 & 0,634 & 0,146 & 0,600 & 0,087 & 0,356 \\
\hline \multirow{2}{*}{5} & Сосна & 0,170 & 0,752 & 0,160 & 0,712 & 0,143 & 0,610 \\
& Лиственница & 0,144 & 0,688 & 0,133 & 0,632 & 0,101 & 0,464 \\
& Береза & 0,179 & 0,806 & 0,169 & 0,762 & 0,104 & 0,452 \\
\hline \multirow{2}{*}{6} & Сосна & 0,138 & 0,733 & 0,130 & 0,720 & 0,107 & 0,595 \\
& Лиственница & 0,144 & 0,698 & 0,130 & 0,650 & 0,083 & 0,425 \\
& Береза & 0,154 & 0,781 & 0,145 & 0,767 & 0,089 & 0,439 \\
\hline
\end{tabular}

Содержание урана в золе корней деревьев (табл. 5). Уран в корнях деревьев достигал своего максимального значения у березы $(0,179$ мг/кг) на водораздельном участке с дерново-подзолистой почвой. Содержание урана в корнях сосны и лиственницы в этих условиях было также высоким (сосна - 0,170 мг/кг, лиственница - 0,144 мг/кг). На склонах содержание урана в корнях деревьев было несколько ниже: 0,138, 0,144, 0,154 мг/кг соответственно для сосны, лиственницы, березы на южном склоне и 0,149 , 0,136, 0,154 мг/кг для тех же видов на северном склоне. Корни древесных растений, растущих на дерновых лесных почвах, накапливали значительно меньше урана, чем на дерновоподзолистых почвах. При этом сохранялась отмеченная для дерново-подзолистых почв закономерность: содержание урана в корнях деревьев на выровненных водораздельных поверхностях (сосна - 0,124 мг/кг, лиственни- ца $-0,119$ мг/кг и береза $-0,143$ мг/кг) было выше, чем на южном (сосна - 0,071 мг/кг, лиственница $-0,064$ мг/кг и береза $-0,079$ мг/кг) и северном (сосна $-0,074$ мг/кг, лиственница 0,071 мг/кг и береза - 0,085 мг/кг) склонах.

Содержаниеуранав золестволовдеревьев (табл. 5). На участках с дерново-подзолистыми почвами максимальное содержание урана в стволах наблюдалось на водоразделе (сосна 0,160 мг/кг, лиственница - 0,133 мг/кг и береза - 0,169 мг/кг). В стволах деревьев, растущих на склонах, накапливалось примерно одинаковое количество урана. На южном склоне стволы сосны содержали 0,130 мг/кг, лиственницы - 0,130 мг/кг, березы - 0,145 мг/кг. На северном склоне стволы сосны содержали 0,138 мг/кг, лиственницы - 0,125 мг/кг, березы - 0,146 мг/кг. Стволы деревьев, произрастающих на дерновых лесных почвах, накапливали уран в меньших количествах, по сравнению с дерново-подзолистыми почвами. 
Максимальное содержание урана достигалось при этом на водораздельном участке (сосна 0,120 мг/кг, лиственница - 0,112 мг/кг, береза - 0,139 мг/кг). Содержание урана в стволах деревьев (сосна - 0,060 мг/кг, лиственница 0,054 мг/кг, береза - 0,049 мг/кг), находящихся на северном склоне, было ниже, чем в стволах деревьев, растущих на южном склоне (сосна 0,071 мг/кг, лиственница - 0,062 мг/кг, береза $-0,069$ мг/кг).

Содержание урана в золе хвои и листьев деревьев (табл. 5). Хвоя и листья деревьев, произрастающих на водораздельном участке с дерново-подзолистыми почвами, содержали больше урана (сосна - 0,143 мг/кг, лиственница - 0,101 мг/кг, береза - 0,104 мг/кг), чем хвоя и листья деревьев, находящихся на склонах. Этот показатель для деревьев, растущих на южном склоне, составлял 0,107, 0,083, 0,089 мг/кг, а на северном - 0,118, 0,092, 0,087 мг/кг для сосны, лиственницы и березы соответственно. Содержание урана в хвое и листьях деревьев, произрастающих на дерновых лесных почвах, было значительно меньше по сравнению с дерново-подзолистыми почвами, и составляло для сосны - 0,055-0,061 мг/кг, для лиственницы - 0,044-0,052 мг/кг, для березы - 0,045-0,049 мг/кг, несущественно различаясь по элементам рельефа.

Содержание урана в золе покровных растений (табл. 6). Содержание урана в надземных частях кустарничков на дерновоподзолистой почве было наибольшим на водоразделе $(0,197$ мг/кг), в направлении склонов оно уменьшалось до 0,189 мг/кг на южном склоне и 0,104 мг/кг - на северном. Содержание урана в корнях кустарничков уменьшалось в такой же последовательности: водораздел - 0,233 мг/кг, южный склон - 0,194 мг/кг, северный склон - 0,152 мг/кг. Содержание урана в надземных частях разнотравья достигало максимального уровня на водораз-

Таблица 6. Содержание урана и тория в покровных растениях исследуемых экосистем (мг/кг золы)

Table 6. The contents of uranium and thorium in the cover plants of the studied ecosystems (mg/kg ash)

\begin{tabular}{|c|c|c|c|c|c|}
\hline \multirow{2}{*}{ № ПП } & \multirow{2}{*}{ Растение } & \multicolumn{2}{|c|}{ Корни } & \multicolumn{2}{|c|}{ Надземная часть } \\
\hline & & $\mathrm{U}$ & $\mathrm{Th}$ & $\mathrm{U}$ & $\mathrm{Th}$ \\
\hline 1 & $\begin{array}{l}\text { Кустарнички } \\
\text { Мхи } \\
\text { Разнотравье }\end{array}$ & $\begin{array}{c}0,119 \\
- \\
0,076\end{array}$ & $\begin{array}{c}0,472 \\
- \\
0,415\end{array}$ & $\begin{array}{l}0,075 \\
0,354 \\
0,096\end{array}$ & $\begin{array}{l}0,301 \\
0,512 \\
0,312\end{array}$ \\
\hline 2 & $\begin{array}{l}\text { Кустарнички } \\
\text { Мхи } \\
\text { Разнотравье }\end{array}$ & $\begin{array}{c}0,256 \\
- \\
0,155\end{array}$ & $\begin{array}{c}0,384 \\
- \\
0,439\end{array}$ & $\begin{array}{l}0,107 \\
0,387 \\
0,133\end{array}$ & $\begin{array}{l}0,215 \\
0,429 \\
0,270\end{array}$ \\
\hline 3 & $\begin{array}{l}\text { Кустарнички } \\
\text { Мхи } \\
\text { Разнотравье }\end{array}$ & $\begin{array}{c}0,057 \\
- \\
0,076\end{array}$ & $\begin{array}{c}0,259 \\
- \\
0,417\end{array}$ & $\begin{array}{c}0,046 \\
- \\
0,066\end{array}$ & $\begin{array}{c}0,205 \\
- \\
0,334\end{array}$ \\
\hline 4 & $\begin{array}{l}\text { Кустарнички } \\
\text { Мхи } \\
\text { Разнотравье }\end{array}$ & $\begin{array}{c}0,152 \\
- \\
0,132\end{array}$ & $\begin{array}{c}0,315 \\
- \\
0,377\end{array}$ & $\begin{array}{c}0,104 \\
- \\
0,108\end{array}$ & $\begin{array}{c}0,256 \\
- \\
0,342\end{array}$ \\
\hline 5 & $\begin{array}{l}\text { Кустарнички } \\
\text { Мхи } \\
\text { Разнотравье }\end{array}$ & $\begin{array}{c}0,233 \\
- \\
0,218\end{array}$ & $\begin{array}{c}0,475 \\
- \\
0,379\end{array}$ & $\begin{array}{c}0,197 \\
- \\
0,201\end{array}$ & $\begin{array}{c}0,475 \\
- \\
0,358\end{array}$ \\
\hline 6 & $\begin{array}{l}\text { Кустарнички } \\
\text { Мхи } \\
\text { Разнотравье }\end{array}$ & $\begin{array}{c}0,194 \\
- \\
0,179\end{array}$ & $\begin{array}{c}0,515 \\
- \\
0,407\end{array}$ & $\begin{array}{c}0,189 \\
- \\
0,159\end{array}$ & $\begin{array}{c}0,515 \\
- \\
0,390\end{array}$ \\
\hline
\end{tabular}


дельном участке $(0,201$ мг/кг), на склоне южной экспозиции оно снижалось до 0,159 мг/кг и было минимальным на северном склоне $(0,108$ мг/кг). Накопление урана корнями разнотравья сохраняло ту же закономерность: водораздел - 0,218 мг/кг, южный склон 0,179 мг/кг, северный склон - 0,132 мг/кг.

Содержание урана в надземных органах кустарничков на дерновых лесных почвах было максимальным на водоразделе $(0,107$ мг/кг), уменьшалось на северном склоне $(0,075$ мг/кг) и было минимальным на южном склоне $(0,046$ мг/кг). Содержание урана в корнях составляло $0,256,0,119$ и 0,057 мг/кг, на водоразделе, северном и южном склонах соответственно. Мхи в значительном количестве встречались только на водоразделе и северном склоне; содержание урана в них составляло 0,387 и 0,354 мг/кг соответственно. Содержание урана в надземных частях разнотравья было наибольшим на водоразделе (0,133 мг/кг), понижалось на северном склоне $(0,096$ мг/кг) и было наименьшим на южном склоне $(0,066$ мг/кг). Корни разнотравья накапливали уран в наибольшем количестве на водоразделе $(0,155$ мг/кг) и заметно меньше на склонах $(0,076$ мг/кг).

Содержание тория в золе корней деревьев (табл. 5). Максимальная концентрация тория наблюдалась у березы $(0,806$ мг/кг) на водоразделе с дерново-подзолистыми почвами. Содержание тория у сосны при этом составляло 0,752 мг/кг, у лиственницы - 0,688 мг/кг. На дерновой лесной почве водораздела торий накапливался в меньшем количестве: сосна 0,287 мг/кг, лиственница - 0,272 мг/кг, береза $-0,259$ мг/кг. Содержание тория в корнях деревьев на склонах было ниже, чем у деревьев, растущих на водоразделах. На дерновоподзолистой почве концентрация элемента на южном склоне (сосна - 0,733 мг/кг, лиственница - 0,698 мг/кг, береза - 0,781 мг/кг) была выше, чем на северном склоне (сосна 0,602 мг/кг, лиственница - 0,560 мг/кг, береза - 0,634 мг/кг). На склоновых участках с дерновыми лесными почвами содержание тория было примерно одинаковым и составляло у сосны 0,196-0,212 мг/кг, у лиственницы 0,186-0,210 мг/кг, у березы 0,177-0,191 мг/кг.

Содержание тория в золе стволов деревьев (табл. 5). На дерново-подзолистой почве содержание тория в стволах было примерно одинаковымнаводоразделе (сосна-0,712 мг/кг, лиственница - 0,632 мг/кг, береза - 0,762 мг/кг) и южном склоне (сосна $-0,720$ мг/кг, лиственница - 0,650 мг/кг, береза - 0,767 мг/кг). На северном склоне содержание тория в стволах деревьев снижалось (сосна - 0,570 мг/кг, лиственница - 0,526 мг/кг, береза - 0,600 мг/кг). На дерновых лесных почвах накопление тория в стволах было заметно ниже по сравнению с дерново-подзолистыми почвами. Максимальное содержание тория наблюдалось на водоразделе (сосна - 0,246 мг/кг, лиственница 0,231 мг/кг, береза - 0,206 мг/кг). Содержание тория в стволах деревьев на северном склоне (сосна - 0,177 мг/кг, лиственница - 0,174 мг/кг, береза - 0,158 мг/кг) было несколько выше, чем у деревьев на южном склоне (сосна 0,173 мг/кг, лиственница $-0,163$ мг/кг, береза $-0,146 \mathrm{мг/кг).}$

Содержание тория в золе хвои и листьев деревьев (табл. 5). Аккумуляция тория в хвое и листьях деревьев, произрастающих на дерново-подзолистой почве водораздельного участка (сосна - 0,610 мг/кг, лиственница 0,464 мг/кг, береза - 0,452 мг/кг), было выше, чем на склонах. На южном склоне этот показатель составлял для сосны 0,595 мг/кг, лиственницы - 0,425 мг/кг, березы - 0,439 мг/кг. На северном склоне содержание тория в хвое и листьях было у сосны - 0,488 мг/кг, лиственницы - 0,368 мг/кг, березы - 0,356 мг/кг. Хвоя и листья деревьев, произрастающих на дерно- 
вых лесных почвах, содержали значительно меньше тория по сравнению с деревьями на дерново-подзолистых почвах. Максимального значения содержание тория достигало на склонах теневой (сосна - 0,152 мг/кг, лиственница - 0,139 мг/кг, береза - 0,113 мг/кг) и солнечной экспозиции (сосна - 0,151 мг/кг, лиственница - 0,124 мг/кг, береза - 0,106 мг/кг), на водораздельном участке его величина была несколько меньше (сосна - 0,135 мг/кг, лиственница - 0,110 мг/кг, береза - 0,098 мг/кг).

Содержание тория в золе покровных растений (табл. 6). Содержание тория в надземных частях кустарничков на дерновоподзолистых почвах уменьшалось в направлении от южного склона через водораздел к северному склону $(0,515,0,475$ и 0,256 мг/кг соответственно). Корневые части растений проявляли такую же закономерность: южный склон - 0,515 мг/кг, водораздел - 0,475 мг/кг, северный склон - 0,315 мг/кг. Содержание тория в корнях разнотравья было выше на южном склоне $(0,407$ мг/кг) по сравнению с водоразделом $(0,379$ мг/кг) и северным склоном $(0,377$ мг/кг). Содержание тория в надземных частях разнотравья сохраняло ту же закономерность: южный склон - 0,390 мг/кг, водораздел - 0,358 мг/кг, северный склон 0,342 мг/кг.

Содержание тория в надземных органах кустарничков на дерновых лесных почвах увеличивалось в направлении от южного склона через водораздел к северному склону $(0,205,0,215$ и 0,301 мг/кг соответственно). Содержание тория в корнях составляло 0,259, 0,384 и 0,472 мг/кг соответственно. Мхи в значительном количестве встречались только на водоразделе и северном склоне с дерновой лесной почвой. Концентрация тория в них составляла 0,429 и 0,512 мг/кг, соответственно. Содержание тория в надземных частях разнотравья было наибольшим на южном склоне $(0,334$ мг/кг) по сравнению с водоразделом $(0,270$ мг/кг) и северным склоном (0,312 мг/кг). Корни разнотравья содержали торий в наибольшем количестве на водоразделе $(0,439$ мг/кг), меньше - на склонах $(0,417$ мг/кг - на южном и 0,415 мг/кг - на северном).

Приведенные данные показывают, что накопление урана и тория растениями лесных фитоценозов зависит от принадлежности к той или иной таксономической группе, от почвы, на которой они произрастают, и от расположения на элементах рельефа.

Наблюдалась высокая степень корреляции между содержанием этих элементов в древесных растениях и содержанием их в корнеобитаемом слое (горизонты $\mathrm{A}+\left(\mathrm{A}_{2} \mathrm{~B}\right)+\mathrm{B}+\mathrm{BC}$, $\mathrm{r}=0,87)$ и в почвообразующей породе (горизонт $\mathrm{C}, \mathrm{r}=0,73)$. Такая зависимость обусловливает, в целом, более высокое содержание урана и тория в растениях, произрастающих на дерново-подзолистых почвах, которые отличаются более высоким содержанием этих элементов. Корреляция по отношению к отдельным горизонтам была не столь высокая, что говорит, по-видимому, о неравнозначности поступления элементов из этих горизонтов в древесные растения. В отличие от деревьев содержание урана и тория в покровных растениях коррелировало с их содержанием в аккумулятивном (гумусовом) горизонте, что говорит об этом слое почвы как об основном источнике их поступления.

Вычисление отношения тория к урану $(\mathrm{Th} / \mathrm{U})$ в растениях и почвах показало заметную изменчивость этой величины, что свидетельствует о существенных различиях в процессах миграции и аккумуляции этих элементов в экосистемах. Th/U-отношение в дерново-подзолистых почвах составляло, в среднем, 4,0, а в дерновых лесных почвах 3,1. В стволах сосны, как преобладающей 
лесной породе исследуемых фитоценозов, $\mathrm{Th} / \mathrm{U}$-отношение на дерново-подзолистых почвах составляло 4,7, а на дерновых лесных - 2,3. Эти данные говорят о том, что растения на дерново-подзолистых почвах более интенсивно поглощают торий по сравнению с ураном. На дерновых лесных почвах поглощение урана снижается относительно поглощения тория. Аналогичная закономерность прослеживается и для стволов лиственницы (4,3 - на дерново-подзолистых, 2,5 - на дерновых лесных) и березы (4,5 - на дерновоподзолистых, 2,4 - на дерновых лесных).

Для оценки способности растений к поглощению урана и тория рассчитывали коэффициенты биологического поглощения (КБП $\left.{ }_{\mathrm{Th}, \mathrm{U}}\right)$, равные отношению их содержания в золе растений $\left(\mathrm{C}_{\mathrm{p}}\right)$ к их содержанию в прокаленной почве $\left(\mathrm{C}_{\mathrm{n}}\right)$ : КБП $=\mathrm{C}_{\mathrm{p}} / \mathrm{C}_{\mathrm{n}}$. КБП Тh, pacсчитанные для содержания тория в стволах деревьев и корнеобитаемом слое (горизонты $\left.\mathrm{A}+\left(\mathrm{A}_{2} \mathrm{~B}\right)+\mathrm{B}+\mathrm{BC}\right)$ дерново-подзолистой почвы равны 0,086 (сосна), 0,078 (лиственница) и 0,096 (береза). КБП сна), 0,067 (лиственница), 0,084 (береза). В фитоценозах на дерновой лесной почве КБП Тh составляли 0,043 (сосна), 0,041 (лиственница), 0,038 (береза). КБП Ч были равны 0,048 (сосна), 0,043 (лиственница), 0,054 (береза). Видно, что на дерново-подзолистой почве накоплению исследуемых элементов стволами деревьев способствует не только более высокая их концентрация в почве, но и другие особенности этой почвы. Корреляционный анализ показывает высокую степень корреляции КБП Тh с кислотностью почвенной среды $(\mathrm{r}=-0,81)$, содержанием физической глины $(\mathrm{r}=0,88)$, мощностью корнеобитаемого слоя $(\mathrm{r}=0,75)$, в меньшей степени с содержанием гумуса $(\mathrm{r}=-0,24)$. Коэффициенты корреля-

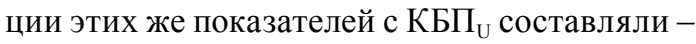
0,$73 ; 0,71,0,76$ и $-0,33$ соответственно.
Определение урана и тория в покровных растениях показало более интенсивное накопление этих элементов по сравнению с древесными растениями, причем уран поглощался интенсивнее, чем торий. КБП урана кустарничками на дерново-подзолистой почве равнялся в среднем 0,141 , а тория $-0,063$. Те же показатели для дерновой лесной почвы равнялись 0,071 и 0,053 . КБП групп растений показали аналогичную тенденцию. Эти данные говорят о том, что торий в гумусовом горизонте закреплен более прочно по сравнению с ураном.

Содержание урана и тория в золе корней, стволов и хвои (листьев) деревьев можно выразить отношением 1,2:1:0,7. В то же время процентное содержание золы в тех же частях растений равно 5:1:4 (табл. 4). Возможно, что такая существенная разница определяется различиями в механизме поглощения исследуемых радионуклидов и биофильных элементов (K, P, Ca, $\mathrm{Mg}, \mathrm{S}$ ), которые количественно преобладают в золе растений.

Общее содержание урана и тория в компонентах исследуемых экосистем соответствовало выявленным выше закономерностям и выглядело следующим образом (табл. 7). Основная масса радионуклидов содержалась в почвах: уран от 7,9 до 33,5 г/га; торий от 34,6 до 133,7 г/га. Содержание урана в стволах деревьев изменялось в пределах от 43,9 до 75,7 мг/га, тория - от 87,1 до 324,2 мг/га. Расчетное содержание радионуклидов в корнях было несколько выше: урана - от 40,5 до 110,3 мг/га, тория - от 113 до 560 мг/га. Содержание радионуклидов в листьях (хвое) деревьев было на порядок меньше, чем в стволах и корнях. В корнях покровных растений содержание урана было в пределах от 8,1 до 11,2 мг/га, тория - от 18,8 до 51,0 мг/га. Надземная часть покровных растений по содержанию радионуклидов незначительно от- 
Таблица 7. Содержание урана и тория в основных компонентах исследуемых экосистем (мг/га)

Table 7. The contents of uranium and thorium in the main components of the studied ecosystems (mg/ha)

\begin{tabular}{|c|c|c|c|c|c|c|c|c|}
\hline \multirow{2}{*}{ № ПП } & \multirow{2}{*}{ Элемент } & \multicolumn{3}{|c|}{ Деревья } & \multicolumn{2}{|c|}{ Покровные } & \multicolumn{2}{c|}{ Почва } \\
\cline { 3 - 9 } & & Стволы & $\begin{array}{c}\text { Хвоя } \\
\text { (листья) }\end{array}$ & Корни & $\begin{array}{c}\text { Надзем- } \\
\text { ные органы }\end{array}$ & Корни & $\begin{array}{c}\text { Лесная } \\
\text { подстилка }\end{array}$ & $\begin{array}{c}\text { Корне- } \\
\text { обитаемый } \\
\text { слой }\end{array}$ \\
\hline \multirow{2}{*}{1} & $\mathrm{U}$ & 43,9 & 5,4 & 42,7 & 7,2 & 8,1 & 3,7 & 17610 \\
& $\mathrm{Th}$ & 87,1 & 15,5 & 120,0 & 18,6 & 21,0 & 10,9 & 47073 \\
\hline \multirow{2}{*}{2} & $\mathrm{U}$ & 66,0 & 5,9 & 78,9 & 10,8 & 10,8 & 5,1 & 27468 \\
& $\mathrm{Th}$ & 131,1 & 13,1 & 177,6 & 20,7 & 22,5 & 12,0 & 51600 \\
\hline \multirow{2}{*}{3} & $\mathrm{U}$ & 64,6 & 5,1 & 40,5 & 8,5 & 9,4 & 2,3 & 7928 \\
& $\mathrm{Th}$ & 102,8 & 14,1 & 113,0 & 17,6 & 18,8 & 7,6 & 34600 \\
\hline \multirow{2}{*}{4} & $\mathrm{U}$ & 50,8 & 7,2 & 92,9 & 10,7 & 10,7 & 17,6 & 18785 \\
& $\mathrm{Th}$ & 216,2 & 38,9 & 376,6 & 38,4 & 41,2 & 71,8 & 75061 \\
\hline \multirow{2}{*}{5} & $\mathrm{U}$ & 75,7 & 12,2 & 110,3 & 10,1 & 11,2 & 38,2 & 31520 \\
& $\mathrm{Th}$ & 318,5 & 52,5 & 491,2 & 39,5 & 46,4 & 142,8 & 126883 \\
\hline \multirow{2}{*}{6} & $\mathrm{U}$ & 59,7 & 10,6 & 107,3 & 8,9 & 10,3 & 20,3 & 33458 \\
& $\mathrm{Th}$ & 324,2 & 57,9 & 559,4 & 41,7 & 51,0 & 66,0 & 133685 \\
\hline
\end{tabular}

личалась от корней. Она накапливала уран в пределах от 7,2 до 10,8 мг/га, торий - от 17,6 до 41,7 мг/га. Заметное количество радионуклидов аккумулировалось в подстилке: урана - 2,3-38,2 мг/га; тория - 7,6-142,8 мг/га. В целом, как следует из табл. 7, экосистемы с дерново-подзолистыми почвами содержали значительно большее количество урана и тория во всех своих компонентах, чем таковые с дерновыми лесными почвами. Это было связано с более высоким содержанием радионуклидов в почвообразующей породе дерново-подзолистых почв и, вероятно, с более высокой кислотностью данных почв, усиливающей миграционную способность этих радионуклидов.

\section{Заключение}

Накопление естественных элементов урана и тория древесными, кустарнико- выми и травянистыми растениями было выше в фитоценозах, сформировавшихся на дерново-подзолистых почвах, которые содержали большее количество этих элементов по сравнению с дерновыми лесными почвами. Содержание урана и тория в деревьях было наибольшим в корнях, наименьшим - в хвое (листьях). Стволы по содержанию этих элементов занимали промежуточное положение. В кустарничках и травянистых растениях содержание урана и тория в корнях было в целом выше, чем в надземных частях. Распределение урана и тория между компонентами исследуемых экосистем зависело от видового состава растительности, содержания этих радионуклидов в почве и почвообразующей породе, конкретных свойств почвы (типовая принадлежность, гумус, $\mathrm{pH}$, гранулометрический состав и др.) и от расположения на элементах рельефа.

\section{Список литературы}

Атлас Иркутской области (1962) М.-Иркутск, ГУГК, 182 с. [Irkutsk Region Atlas (1962) Moscow, Irkutsk, State department of geodesy and cartography, 182 p. (in Russian)] 
Гродзинский Д.М. (1965) Естественная радиоактивность растений и почв. Киев, Наук. Думка, 216 c. [Grodzinsky D.M. (1965) Plants and soils natural radioactivity. Kiev, Naukova dumka, 216 p. (in Russian)]

Добровольский В.В. (2001) Практикум по географии почв с основами почвоведения. М., Гуманит. изд. центр ВЛАДОС, 144 с. [Dobrovolsky V.V. (2001) Practical course on pedogeography and pedology basics. Moscow, Humanitarian Publishing Center VLADOS, 144 p. (in Russian)]

Леса и лесное хозяйство Иркутской области (1997) Ващук Л.Н. (ред.) Иркутск, 288 с. [Forests and forestry of Irkutsk region (1997) Vashuk L.N. (ed.) Irkutsk, 288 p. (in Russian)]

Методические рекомендации по санитарному контролю за содержанием радиоактивных веществ в объектах внешней среды (1980) Марей А.Н., Зыкова А.С. (ред.) М., 336 с. [Guideline on the sanitary control for radioactive materials concentration in external objects (1980) Marey A.N., Zykova A.S. (eds.) Moscow, 336 p. (in Russian)]

Почвы Иркутской области, их использование и мелиораџия (1979) Иркутск, Ин-т географии Сибири и Дальнего Востока, 135 с. [Soils of Irkutsk region, utilization and melioration (1979) Irkutsk, Institute of Geography of Siberia and the Far East, 135 p. (in Russian)]

Титаева Н.А. (2000) Ядерная геохимия. М., Изд-во МГУ, 336 с. [Titaeva N.A. (2000) Nuclear geochemistry. Moscow, Moscow State University, 336 p. (in Russian)]

Титаева Н.А., Таскаев А.И. (1984) Миграџия тяжельх естественных радионуклидов в условиях гумидной зоны. Л., Наука, 232 с. [Titaeva N.A., Taskaev A.I. (1984) Migration of heavy natural radionuclide in a humid zone. Leningrad, Nauka, 232 p. (in Russian)]

Тяжелые естественные радионуклиды в биосфере: Миграция и биологическое действие на популяции и биогеоценозы (1990) Алексахин Р.М. (ред.) М., Наука, 350 с. [Heavy natural radionuclides in the biosphere: Migration and biological impact on populations and biogeocoenoses (1990) Aleksakhin R.M. (ed.) Moscow, Nauka, 350 p. (in Russian)]

Усольцев В.А. (2002) Фитомасса лесов Северной Евразии: нормативы и элементы географии. Екатеринбург, УрО РАН, 572 с. [Usol'tsev V.A. (2002) Phytomass of Northern Eurasia forests: geographical standards and elements. Ekaterinburg, Uralian Branch of the Russian Academy of Sciences, 572 p. (in Russian)]

Швецов С.Г., Гудаев А.В., Иванов А.А. (2006) Мониторинг содержания тяжелых естественных радионуклидов в почве на жидкостном сцинтилляционном счетчике. Почва как связующее звено функиионирования природных и антропогенно-преобразованных экосистем. Мат. П Межд. научно-практ. конф. (Иркутск, 4-7 сентября, 2006 г.). Иркутск, Издво Иркут. гос. ун-та, с. 309-311 [Shvetsov S.G., Gudayev A.V., Ivanov A.A. (2006) Monitoring of heavy natural radionuclides content in soils by the liquid scintillation counter. Soil as a link between functioning natural and anthropogenic-transformed ecosystems. Proceedings of the $2^{\text {nd }}$ Intern. Research and Practice Conference (Irkutsk, September 4-7, 2006). Irkutsk, Irkutsk State University, p. 309-311 (in Russian)]

Шишов Л.Л., Тонконогов В.Д., Лебедева И.И., Герасимова М.И. (2004) Классификаиия и диагностика почв России. Смоленск, Ойкумена, 341 с. [Shishov L.L., Tonkonogov V.D., Lebedeva I.I., Gerasimova M.I. (2004) Classification and diagnostics of soils in Russia. Smolensk, Oykumena, 341 p. (in Russian)] 
Grebenshchikova V.I., Kitaev N.A., Lustenberg E.E., Medvedev V.I., Lomonosov I.S., Karchevskii A.N. (2009) Radioactive elements distribution in the environment of Pribaikal'e. Communication 1. Uranium. Contemporary Problems of Ecology, 2(1): 12-21

Grebenshchikova V.I., Kitaev N.A., Lustenberg E.E., Medvedev V.I., Lomonosov A.N., Karchevskii A.N. (2010) Radioactive elements distribution in the environment of Pribaikal'e. Communication 2. Thorium and cesium-137. Contemporary Problems of Ecology, 3(3): 246-355

Manual on methodologies and criteria for harmonized sampling, assessment, monitoring and analysis of the effects of air pollution on forests (1994) Hamburg and Prague Unated Nations Environment Programme and Economic Commision for Europe, $477 \mathrm{p}$. 